\title{
Michel Houellebecq and the International Sexual Economy
}

\author{
Douglas Morrey \\ University of Newcastle, United Kingdom
}

The French novelist, poet and essayist Michel Houellebecq has, for some time now, proposed various interpretations of what we might call the economy of sexuality. This was made particularly explicit in Houellebecq's first novel, Extension du domaine de la lutte (1996), whose title stems from the author's contention that any struggle against the concentration of economic power must also extend to the domain of sexual power (the novel's title in the English translation, Whatever, unfortunately loses all the polemical value of the original French). The novel painted a disturbing portrait of those who, denied access to sexual commerce in the same way that others are denied the benefits of global economic growth, harbour a murderous rage born of their sexual frustration. In his notorious second novel, Les Particules élémentaires (Atomised, 1998), Houellebecq imagined a future in which humanity abandoned sexual reproduction in favour of cloning, grateful for an end to the relentless drudgery of sexual competition.

Houellebecq's concern with the economic role and monetary value of sexuality perhaps reached its apotheosis in his last, highly controversial novel, Plateforme (Platform), published in 2001. Plateforme discusses at length the economies of tourism generally, and sex tourism specifically, and makes the provocative assertion that, in an increasingly globalised world, a kind of generalised sex tourism represents the logical evolution of both the leisure economy and interpersonal relations. No other sector, suggests Houellebecq, will witness such significant growth over the coming century. Houellebecq's argument is that sex in the west has become practically impossible and is, in any case, undesirable. Most of us are simply too busy propping up the service economy to meet new people and, even when such meetings occur, they are usually disappointing. The legacy of western sexual liberation has left us all (but —and let's be clear on this - especially women) with ridiculously high expectations for our sex lives and, although we talk a lot about sex-indeed it often seems like our only topic of conversation - few people actually seem prepared to engage in the activity itself. As a result, it is increasingly common to resort to a purely mechanical discharge of sexual tension via masturbation and the use of pornography. But this simply perpetuates the 
vicious circle of sexual frustration since the idealised bodies of porn stars remind us of our own inadequacies and leave us further disinclined to engage with the banal bodies of our peers. Westerners, concludes Houellebecq, 'ne parviennent plus à ressentir le sexe comme naturel' ('no longer feel sex as something natural') (Houellebecq 2001, p. $236 ; 2003$, p. 244). Faced with this bleak picture, the only solution for the westerner seeking sexual gratification is to go abroad, to indulge in sex tourism. When those in the west have everything but sexual satisfaction and those in the third world have nothing to sell but their bodies, we are faced with 'une situation d'échange idéale' ('an ideal trading opportunity') (Houellebecq 2001, p. 234; 2003, p. 242): sex tourism is quite simply 'l'avenir du monde' ('the future of the world') (Houellebecq 2001, p. 107; 2003, p. 107). Interracial sex further represents the salvation of all those who have been marginalised in the market economy of western sexuality, since the specific characteristics of sexual attractiveness valued at this particular juncture of history are by no means universal and therefore unlikely to pertain in non-western contexts. Besides, as Houellebecq's narrator admits with disarming honesty towards the end of the novel: 'il est moins humiliant de payer pour un être qui ne ressemble à aucun de ceux qu'on aurait pu séduire par le passé, qui ne vous rappelle aucun souvenir' ('it's less humiliating to pay for someone who looks nothing like any of those you have seduced in the past, who brings back no memories') (Houellebecq 2001, p. 343; 2003, p. 354).

There are a number of obvious objections one could make to this situation as presented in Plateforme. Houellebecq's casual sexism and racism are, on occasion, quite breathtakingly offensive and have unsurprisingly drawn strong criticism. His view of the crippled sexuality of the west seems to be based, in no small amount, on his resentment of the social, sexual, and economic gains made by women over the past three decades or so. And he has no hesitation in reducing his portraits of women to a purely sexual description. One of the narrator's first observations about Valérie, who will later become his lover, is that her mouth seems particularly well suited to swallowing sperm (Houellebecq 2001, pp. 48-49; 2003, p. 44). The novel also met with particular condemnation in France for its expression of racist sentiments, especially with regard to the Muslim world, the author even being tried for (and acquitted of) incitement to racial hatred. Houellebecq has stressed, somewhat disingenuously, that his problem is not with Muslims as people but with Islam as a religion, a point he tries 
to convey by putting his tirades about Islam into the mouths of Arab characters, first an Egyptian and later a Jordanian. But this does little to soften the impact of such statements as: 'L'islam ne pouvait naître que dans un désert stupide, au milieu de Bédouins crasseux qui n'avaient rien d'autre à faire [...] que d'enculer leurs chameaux' ('Islam could only have been born in a stupid desert, among filthy Bedouins who had nothing better to do [...] than bugger their camels') (Houellebecq 2001, pp. 243-44; 2003 , p. 251). This practice of inventing minor characters to serve as the mouthpiece for objectionable sentiments occurs again when Michel meets Robert, a fellow French sex tourist and an openly-declared racist, in a Thai massage parlour. Robert insists that the first virtue of travel is to reinforce racial prejudice and that sex tourism can be seen as the harbinger of an impending global interracial war; far from Michel's nuanced economic analysis, Robert characterises sex tourism as a kind of primitive struggle for the sexual conquest of women of colour.

It could, of course, be quite reasonably argued that, in addition to being offensive, Houellebecq's view of the economic and sexual state of the world is just plain wrong. There is some doubt as to how far this notion of western sexual stagnation can be generalised beyond the small, neurotic Parisian cultural class to which Houellebecq and his narrator belong. At one point, wondering who can possibly be responsible for the global domination of the sportswear brands Nike and Adidas besides the juvenile delinquents from the housing projects on the outskirts of Paris, Michel admits: 'Il devrait y avoir des secteurs entiers de la société qui me demeuraient étrangers' ('Clearly there had to be whole sectors of society who were still alien to me') (Houellebecq 2001, p. 263; 2003, p. 272). Indeed so, and to begin with the massed, anonymous ranks of provincial middle-class families who keep the consumer society ticking over. It can sometimes be tempting to dismiss Houellebecq's arguments as the self-obsessed whining of a single sexual inadequate. The question, I suppose, is the extent to which the profound sexual disappointment of Houellebecq's anti-heroes is representative of real emotions existing within our societies. The tremendous, almost unprecedented commercial success of his writing would certainly suggest that it is.

Given the undoubted popularity of Houellebecq's work, it is worth considering his arguments seriously, particularly as his view of the global economic situation bears comparison to certain theoretical apprehensions of the same phenomenon, notably in 
the philosophy of Jean-François Lyotard. Lyotard was, of course, one of the first thinkers to present a sustained theoretical elaboration of the postmodern economy. The goal of this post-industrial economy, argues Lyotard, is to produce, in the first instance, not material goods but information, and this information serves to increase the complexity and performativity of the system as a whole. The more information one has at one's disposal, the less likely one is to be caught unawares by an unpredictable event. By calculating the probability of such an event in terms of risk, postmodern capitalism seeks to give it a monetary value, a sum that can then be stored to safeguard against any such undesirable eventuality. What this means, though, is that the present is routinely subordinated to the future and so, in human terms, the desire for pleasure in the here and now is repeatedly frustrated by the constant injunction to save, both time and money (Lyotard 1988, pp. 77-79). The deferral of sensual gratification is - in an apparent paradox - accompanied by a proliferation of sexual representation. As Pierre Klossowski has argued, sensual pleasure is adjourned in favour of the more 'urgent' needs of sustenance and survival, but, since the sexual drive itself knows no deferral, it becomes urgent that it be represented (1997 [1970], p. 52).

The inability to catch up with ourselves, in temporal, financial or libidinal terms, that Lyotard stresses in his description of contemporary capitalism, is clearly presented in Houellebecq's novel. When reading popular American fiction by John Grisham and David Balducci, Michel is struck by the way that characters are defined by the number of hours they work: 80, 90, 110 hours per week; and later, Jean-Yves, Valérie's boss at the tourism company, will be described as working twelve to fourteen hours a day. Valérie, admitting that she takes little satisfaction from her work, identifies the need to rethink her life, if only she had the time. Free market capitalism offers no respite, she explains to Michel: if you do not maintain an advantage over the competition through constant innovation, you will not survive. The first and most basic reason why sex has become impossible in the west is that we simply have no time. As Michel laments at the end of the novel: 'Nous avons créé un système dans lequel il est devenu simplement impossible de vivre; et, de plus, nous continuons à l'exporter' ('We have created a system in which it has simply become impossible to live; and what's more, we continue to export it') (Houellebecq 2001, p. 349; 2003, p. 361).

As the postmodern economy of western capitalism continues to absorb the rest of the 
globe, states Lyotard, its goal is not to improve our knowledge or tolerance of other cultures, but simply to assimilate them as components with which to improve the complexity and performativity of the system as a whole. In practice, this results not in improved communication and sensitivity, but in the growth of poverty and illiteracy (Lyotard 1988, p. 75). As Michel notes, Thailand's entry into the global market economy brought about a rapid devaluation of its currency, ending two hundred years of peace and prosperity. The corporate headquarters of the Aurore tourism group on the outskirts of Paris in Evry becomes a microcosm for the inequalities of the global economy: while armed guards watch over the executives at work inside, a couple of miles away disenfranchised youths riot in bleak housing projects. Jean-Yves envisions a future on the model of São Paolo, where the executive class moves from high-rise to high-rise, travelling exclusively by helicopter, the streets below having been definitively abandoned to the poor. It is in this context that Michel's projected image of affluent westerners exchanging cash for sex on third world beaches takes on a certain grim realism. Although never expressing anything but contempt for global capitalism, Michel seems to recognise its ineluctable character. For Michel, it seems, economy is history, that is to say economic progression is an abstraction of the movement of history itself. He suggests as much when discussing his experimental attempt to keep up with current affairs by reading only the financial pages of the newspaper. And, in a move that would appear to equate to Lyotard's notion of a libidinal economy (Lyotard 1974), Michel implies that the flow of desire is contiguous to, and often overlapping with, the flow of capital and, as such, just as impersonal and ungovernable.

If the dispassionate gaze that is cast over humanity in Houellebecq's novel frequently appears objectionable, it is perhaps largely because of the virulent anti-psychologism by which it is characterised. The novel refuses to present its characters as the conjuncture of individual psychological circumstances, portraying them instead as representative of broad social trends. Indeed, Michel argues that our obsession with individualism, identity politics and rights is a significant factor contributing to our sexual stalemate. (The cloned future of Les Particules élémentaires is imagined precisely as an escape from this tiresome egocentrism.) Plateforme begins like a psychological novel with the death of the narrator's father, yet immediately proceeds to empty this event of individual significance. The death of Michel's father is statistical evidence of the mounting sexual tension between races discussed elsewhere in the 
novel, since he is murdered by the brother of the Arabic maid with whom he has been sleeping. But Michel himself remains impassive when confronted with the death of this man with whom he had no significant relationship. Other deaths in the novel are the occasion for remarks upon the futility and banality of existence: the death of Jean-Yves's father brings to the close a life without incident, prompting Houellebecq to write: 'C'est sans doute à tort qu'on soupçonne chez tous les êtres une passion secrète, une part de mystère, une fêlure' ('We are probably wrong to suspect that each individual has some secret passion, some mystery, some weakness') (Houellebecq 2001 , p. 278; 2003, p. 288). And, when Michel is preparing to die at the end of the novel, he is under no illusions as to the importance of his own life: 'j'aurai été un individu médiocre, sous tous ses aspects [...] On m'oubliera. On m'oubliera vite' ('I will have been a mediocre individual in every possible sense [...] I'll be forgotten. I'll be quickly forgotten') (Houellebecq 2001, pp. 350-51; 2003, pp. 361-62).

This refusal of individual psychology leads Houellebecq repeatedly to explode the limits of political correctness. For, if racial and sexual generalisations are held to be offensive, it is because they rob us of our sense of individuality, of psychological uniqueness. But Jean-Yves argues that racial discrimination is sensible, not to say inevitable. He notes that he would be reluctant to hire someone of North African origin to work in public relations due to the number of clichés about Arabic life routinely used to sell North African destinations to tourists; on the other hand, the same candidate might be ideal to handle negotiations with local service providers: 'Les origines des gens font partie de leur personnalité, il faut en tenir compte, c'est évident' ('A person's origins are part of their personality, you have to take them into consideration, it's obvious') (Houellebecq 2001, p. 195; 2003, p. 201). To suggest that we are all unique individuals is ultimately to partake of the metaphysical fiction of the eternal soul. Michel says as much to a psychiatrist who is counselling him after the death of Valérie in a terrorist attack on a holiday resort in Thailand. When the psychiatrist suggests that Michel needs to free himself from his attachment, Michel responds: 'Je n'étais qu'un attachement. De nature transitoire, je m'étais attaché à une chose transitoire, conformément à ma nature [...] Aurais-je été de nature éternelle [...], que je me serais attaché à des choses éternelles' ('I was nothing more than an attachment. Inclined to the transitory by nature, I had become attached to a transitory thing, as was my nature [...] Had I been inclined towards the eternal by nature [...], I would have become attached to 
things eternal') (Houellebecq 2001, p. 333; 2003, p. 345).

More than the unique psychology of individuals, then, Houellebecq is interested in describing the collective behaviour of larger social groups. That said, he has no more time for sociologists than he does for psychologists, including in his novel a scene that ridicules the banal observations of a behavioural sociologist and ironically citing an article from the Annals of Tourism Research whose conclusions are quite stunning in their obviousness. Michel meanwhile describes with amused detachment the herd instincts of the group of tourists on his package holiday, particularly with regard to seating arrangements at mealtimes. The detachment of the narration is such that these descriptions frequently take on an almost evolutionary scope: the few complimentary remarks that Michel finds to make about humanity are in this Darwinian spirit: man, he grudgingly admits at one point, is 'un mammifère ingénieux' ('an ingenious mammal') (Houellebecq 2001, p. 103; 2003, p. 102); elsewhere, the lush tropical vegetation in Thailand inspires him to remark upon the courage required for humanity to colonise the cold regions of the planet (Houellebecq 2001, p. 119; 2003, p. 120). Two American tourists sizing up the lobsters in a restaurant are presented as a tableau of 'Deux mammifères devant un crustacé' ('two mammals in search of a crustacean') (Houellebecq 2001, p. 105; 2003, p. 105) whilst Michel compares himself favourably to a toad, noting: 'mon espérance de vie était analogue à celle d'un éléphant, ou d'un corbeau; j'étais quelque chose de bien plus difficile à détruire qu'un petit batracien' ('my life expectancy was comparable to that of an elephant, or of a crow; I was much more difficult to destroy than a small batrachian') (Houellebecq 2001, p. 128; 2003, p. 130). Nonetheless, all life must come to an end, and Plateforme demonstrates a certain morbid preoccupation with this general principle of entropy. On more than one occasion, Houellebecq characterises life as a process of immobilisation or anchylosis whereby the things one was capable of in one's youth gradually come to appear impossible. We might go so far as to say that, in Houellebecq's analysis, western sexuality itself has almost attained this ultimate state of inarticulation, and that his view of an international sexual economy merely represents that next evolutionary step for human sexuality.

By discussing sexuality on this evolutionary scale and refraining from making moral judgements about it, Houellebecq's novel bears the influence, albeit largely unspoken, 
of Friedrich Nietzsche. I say largely unspoken because, at one point, following an overview of Thai history, Michel comments 'La volonté de puissance existe, et se manifeste sous forme d'histoire' ('The will to power exists, and it manifests itself in the form of history') (Houellebecq 2001, p. 82; 2003, p. 80). For Nietzsche, this will to power is the most basic of drives, indeed it is simply the will to life. Life is a process of 'continually shedding something that wants to die' (Nietzsche 2001 [1887], p. 50), of subsuming the weak to the strong. Since this is a question of necessity, says Nietzsche, it cannot be one of morality. Our tendency to discuss the processes of life in terms of morality stems from an anthropomorphic view of the world: the world, Nietzsche insists, 'is neither perfect, nor beautiful, nor noble, nor does it want to become any of these things' (2001, p.109), it has no purpose and obeys no laws. Morality always operates to benefit a particular group at a particular time, and that which is judged immoral, or evil, is usually only that which is new. To want to eradicate cruelty and misery from the world is to want to cease all development, all change, yet this is the natural and only possible state of the world. This consideration of the paradoxes of morality within society informs Nietzsche's view of the development and decline of civilisations. The construction of something like an ideal free society requires the renunciation, or denial, of individual freedom in favour of the common good. But once freedom is attained, individuals are reluctant to give up that freedom, such that the continued development of that society eventually founders in decadence, leaving it open to attack or colonisation by neighbouring societies.

This is precisely the mutation described in Les Particules élémentaires: the sexual liberation and utopian aspirations of the late-sixties counter-culture movements are seen to be largely responsible for today's depressing impassivity before questions both moral and sexual, a cultural cul-de-sac that can only be transcended through an unlikely collective renunciation of individual freedom in the interest of the species. The grand, trans-human scale of these considerations is, however, not incompatible with the kind of ethics of sexuality discussed by Foucault in his account of ancient Greece. There, says Foucault, the excessive tendency of desire was recognised, not as an evil, as in the Christian tradition, but as its natural state (1984, p. 69). An ethics of sexuality must therefore address the question of how best to contain this excess within an economy. Sexual morality is not a matter of proscribing certain acts or condemning desire itself, but a question of the attitude one takes towards pleasure (p. 69). From this point of 
view, Houellebecq's fictions would simply seem to suggest that the current economy of desire is failing to contain this excess, and his ambiguous utopias merely argue for a different way of managing this libidinal economy.

In Plateforme, Houellebecq describes a world in which the great emancipatory promises of the eighteenth and nineteenth centuries have reached their term. Whether these great projects of humanity have been a success - as in western Europe - or a failure - as in socialist Cuba - is ultimately of little importance. What matters is that the world is ripe for the next phase of its evolution and the flow of desire and capital, the erotic and economic exchange between east and west, north and south, marks the beginning of that evolution. Michel is only happy that he won't be a part of it: 'Des mutations surviendraient, survenaient déjà, mais je n'arrivais pas à me sentir réellement concerné; ma seule motivation authentique consistait à me tirer de ce merdier aussi rapidement que possible' ('Mutations would occur, were already occurring, but I found it difficult to feel truly concerned; my only genuine motivation was to get the hell out of this shithole as quickly as possible') (Houellebecq 2001, p. 288; 2003, p. 299).

If all this appears unrelentingly pessimistic, it is to reckon without the playful humour with which Houellebecq presents these undoubtedly serious observations. In this, too, Houellebecq is similar to Nietzsche, to the mischievous writer much admired by Deleuze and Derrida who, hiding behind a series of masks, ultimately implies that there is nothing behind the mask, no truth behind the succession of appearances. Dominique Noguez has lamented the way in which the furore around Houellebecq's novels has rendered them all but invisible as writing (Noguez 2003, p. 20). In a lengthy analysis of the author's style, Noguez concludes that, if some of his pronouncements have become so infamous, it is largely thanks to the skill with which Houellebecq formulates them (p. 97). In a similar spirit of recuperation, I want to analyse the ironic narrative humour with which Houellebecq reinforces his argument in Plateforme, preventing his first-person narrator from taking on the stature of a unified and authoritative ego.

There is a persistent strain of self-deprecation in the work that balances the tendency towards self-pity and lends an ironic edge to Houellebecq's grand pronouncements about the future of human sexuality. Initially we might note that Houellebecq's insistence on the impossibility of encountering a happy and fulfilled sexuality in the 
west seems comprehensively undone by the narrative of Plateforme in which Michel falls in love and has frequent, graphic and imaginative sex with Valérie. Indeed we might argue that the terrorist attack that kills Valérie at the end of the novel is a deus ex machina necessitated by Houellebecq's resolutely pessimistic discourse. And yet, if we look a little closer, we might suggest that Michel and Valérie's relationship never exists at all except on the level of fantasy. In the first section of the novel, Michel is repeatedly characterised by his social and sexual incompetence, his almost total withdrawal from any sexual activity that cannot be paid for. At one point he has an erotic dream about making love to a black woman on the Metro in Paris but dismisses it with the words: 'Tout cela ne pouvait en aucun cas se produire. C'était un rêve de famine, le rêve ridicule d'un homme déjà âgé' ('Such things could never happen under any normal circumstances. It was the dream of a starving man, the ludicrous dream of a man already grown old') (Houellebecq 2001, p. 86; 2003, p. 84). When Michel suggests to Valérie that they could see each other again in Paris, she responds with contempt and, upon his return to France, Michel settles down for a weekend with a roast chicken, two bottles of booze and a copy of Hot Video.

In this context, Michel's subsequent phone call to Valérie, and the passionate sex that ensues when he is barely through her front door, appear utterly fantastical, the relationship coming across as a pure dream of wish fulfilment. Indeed, immediately after they first make love, a descriptive passage suddenly seems to place us back in Thailand. This is quickly revealed as a dream, and yet tends to have the effect of undermining the reality of the sex scene that has gone before. The erotic episodes with Valérie that regularly punctuate the remainder of the novel are like so many sequences from pornographic movies: a threesome with the maid in Cuba; a foursome with a black couple involving double penetration; sex on a train; another threesome in the steam-room of a health club; another foursome with two Thai girls and so on. At times it is difficult not to read this as simply a masturbatory fantasy, and Houellebecq perhaps slyly acknowledges as much when he shows us Michel beating off to a scene in John Grisham's The Firm. He is unperturbed when his sperm sticks the pages together, reasoning that 'ce n'était pas un livre à lire deux fois'! ('it wasn't the kind of book you read twice')! (Houellebecq 2001, p. 91; 2003, p. 89) At the end of the novel, Michel is miraculously unharmed by the explosion that kills Valérie along with 116 other people, casting further doubts on the reality of the whole affair. The novel's epilogue, in which 
Michel returns alone to Thailand in order to end his days amongst the sexual detritus of western civilisation in Pattaya, could quite easily be understood as the direct continuation of Michel's earlier visit to the country, with the book's entire middle section dismissed as fantasy. In other words, it is a little as though, having needed the narrative device of Valérie and her job in tourism to facilitate the exposition of his ideas about an international sexual economy, Houellebecq sought, in addition, to reveal its status as narrative device, in order to underline his argument about the sterile cul-de-sac of western sexuality. But it is worth pointing out that the novel never actually invites the reader to consider Michel's narrative as a subjective fantasy since, as we have said, Plateforme is not a psychological novel. Rather, this narrative irony comes to be inscribed within the very structure of the work, as a result of the contradictions implied by trying to criticise the postmodern sexual economy without ever being able to speak from a position outside it.

At one point in Plateforme, Michel, who works for the Ministry of Culture, listens to the pitch of a contemporary artist whose work consists of making plastic moulds of her clitoris. Inspired by this to take a closer look at Valérie's anatomy, Michel succeeds in bringing her more quickly to a more satisfying orgasm. Thus, these mini sculptures will have fulfilled the traditional function of art, muses Michel, since they encouraged him to 'porter un regard neuf sur le monde' ('see the world in a new light') (Houellebecq 2001, p. 293; 2003, p. 305). Much like the earlier joke at the expense of The Firm, then, this episode implies the degradation of the humanist view of artistic value, and yet it also suggests, however facetiously, that art can still have immediate material benefits. It is ultimately perhaps in this spirit of the inevitable compromise demanded by the cultural marketplace, that Plateforme takes up position: as a work with serious points to make about the evolution of sexuality within a globalised economy, but never at the expense of a good wank.

\section{Reference List}

Foucault, M. 1984, Histoire de la sexualité II: L'usage des plaisirs, Gallimard (coll. Tel), Paris.

Houellebecq, M. 2001, Plateforme, Flammarion (coll. J'ai lu), Paris. Houellebecq, M. 2003, Platform, trans. by F. Wynne, Vintage, London. Klossowski, P. 1997 (1970), La Monnaie vivante, Rivages poche, Paris. Lyotard, J.-F. 1974, Économie libidinale, Minuit, Paris.

Lyotard, J.-F. 1988, L'Inhumain: Causeries sur le temps, Galilée, Paris, 
Nietzsche, F. 2001 (1887), The Gay Science, trans. by J. Nauckhoff, Cambridge University Press, Cambridge.

Noguez, D. 2003, Houellebecq, en fait, Fayard, Paris. 